\title{
Displacement Effect on Local Traders by Emerging Markets: Durban Townships
}

\author{
Machawe Victor Dlamini ${ }^{1}$ and Thokozani Patmond Mbhele ${ }^{2, *}$
}

\author{
${ }^{1}$ 32a Forbes Drive, St Hillier, Gillits, South Africa \\ ${ }^{2}$ Discipline of Supply Chain Management, School of MIG, University of KwaZulu-Natal (Westville Campus), \\ Private Bag X54001, Durban, 4000, South Africa
}

\begin{abstract}
The propounded omnipresent of township malls and aggressive suppliers' expansion into the emerging markets epitomises the greater potential to create jobs and improve the economic transformation. However, it is important to note that these developments could trammel local traders' economic prosperity than abrupt veracity of growth and symbiotic trajectory. While the encroachment of mainstream retailers into South African township markets offers business opportunities and economies of scope to consumers. The objectives which underpinned this study: to explore local township traders' perceptions on the displacement effects from shared value-creation in emerging markets; and to establish the extent of the transformation of retail enterprise development and the displacement of local traders. The study used quantitative methods to analyse the data collected from 301 respondents to amass primary data. The study found that, while local traders appreciate the transformation and development of the townships brought about by shopping mall development, their businesses have been displaced by the emergence of township malls.
\end{abstract}

Keywords: Emerging markets, local traders, displacement effect, and shared value systems.

\section{INTRODUCTION}

The emerging markets resemble modern South African reconfigured economy with local urban township traders and mainstream or formal sector. The local township traders include micro, medium and small scale businesses in the townships, while the mainstream formal sector includes commercial large scale businesses. Thus, this paper seeks to establish the local township traders' perceptions on the influence of emerging markets whether these markets tend to transform landscape of township operations or displace the small scale operations in the emerging economy. For this paper, the terms emerging markets and township malls are used interchangeably in the context of township development and transformation. The distribution interlinkage in the extended supply chain enterprises includes the tier-based and lead supplier, the intermediary/distributor, the retailer and the consumer. The distribution volume determines the scalability between a small scale to the emerging markets and large scale in the mainstream economy. While mainstream retailers provide a wide variety of products in bulk and breaking bulk, broadly, emerging markets known as extended shopping malls are characterised by an increase in personal disposable income among previously disadvantaged groups. According to Strydom (2011, 164) traditionally, "suppliers used intermediaries to distribute their

*Address correspondence to this author at University of KwaZulu-Natal (Westville Campus), Private Bag X54001, Durban, 4000, South Africa; Tel: +2731 260 7524; E-mail: mbhelet@ukzn.ac.za products, in recent times, distributors are being used for delivery and product availability directly to the consumer". Large chain stores are expanding into newly-developed malls in South African townships (Strydom, 2011, 164; Hauke \& Kossowski, 2011). These markets present both benefits and challenges to the consumer, retailer and supplier while the small scale businesses depict the indifferences on township economic transformation. Nevertheless the large scale businesses are tapping into increased consumer disposable income, "local township traders have experienced a shrinking market" (Hauke \& Kossowski, 2011).

The expansion of mainstream retailers into KwaMashu and Umlazi townships for this paper offers business opportunities, economies of scope and choice for consumers, and frequencies to product availability within proximity. Beyond the posing threat of displacement effect on local businesses, retailers' proximity to the final consumer has "propensity to more affordable prices for local consumers, improved living standards and competition in these emerging markets" (Tustin \& Strydom, 2006, 49). This paper thus explores the perceptions of local traders in emerging markets in the two largest townships in KwaZulu-Natal (KZN) province. It focuses on Kwa-Mashu with a population of 175663 spread over $21.47 \mathrm{~km}^{2}$ and three major shopping complexes (Bridge City, K-station and Lcomplex), and Umlazi, with a population of 404811 spread over $47.46 \mathrm{~km}^{2}$ and three major shopping malls (Mega City, Spar Philani Shopping Complex and Kwa- 
Mnyandu Shopping Mall) (Frith, 2014, 44). The study focuses on two biggest townships in KwaZulu Natal province to cover sufficient elements of emerging markets on the virtue size, diverse business categories and propensity to growth.

Retailers and suppliers need to formulate a winning business strategy in penetrating township markets and understanding the local shoppers in the fast moving consumer goods (FMCG) sector (Gonzalez \& Waley, 2013, 966). Organisations that have successfully penetrated the emerging market have used route to market as an important aspect of their expansion strategy, South African Breweries (SAB/InBev), Brandhouse, Unilever and Proctor \& Gamble (P\&G) are examples (Gonzalez \& Waley, 2013, 973). Tustin \& Strydom $(2006,61)$ acknowledge that the local township trading landscape is dynamic and changes over time, whereby many businesses are owned by foreigners who depict dynamism and unconventional perspective on business approaches. The majority of local Spaza shops, supermarkets, liquor stores, hardware, butchery and pharmaceuticals are wellmanaged with sound record keeping and technological devices such as credit card facilities for consumers and stay open for longer hours seven days a week. Neves \& Du Toit $(2012,131)$ have depicted that local township traders' activities are "embedded in a social context where relationships of mutual support and reciprocity can be as important as profit motives, whilst economic participation itself serves as social function and reinforces peoples' sense of belonging, place in community and self-identity".

\section{RESEARCH PROBLEM AND OBJECTIVES}

The emergence of township malls and suppliers' expansion into the townships has the possibility of creating jobs and improving the quality of goods and services. It is equally important to note that the emergence of large chain stores activities in local townships could negatively affect local township traders and commence displacement effect. The influence of emerging markets on the optimal structured cost of the distribution model and propensity to improve product availability has fundamental precursors or absorption towards competitive advantage. The objectives which underpinned this study: (i) to explore local township traders' perceptions on the displacement effects from shared value-creation in emerging markets; (ii) to establish the extent of the transformation of informal retail enterprise development and the displacement of local traders as a result of the entry of both large-scale suppliers and retailers into township markets.

\section{CONCEPTUAL FRAMEWORK}

This paper focuses on value creation by local traders in emerging markets in order to stay competitive. Wedan $(2006,3)$ notes that, in order to leverage opportunities in emerging markets, "retailers must transition from serving a limited number of customers to catering for a broader market in an efficient and responsive manner that reduces the cost of sourcing goods and services". The study thus sought to understand the transformation of retail enterprise development by formalised large scale chains through an architecture of mainstream supply chain networks. Presumably, this township supply chain integration

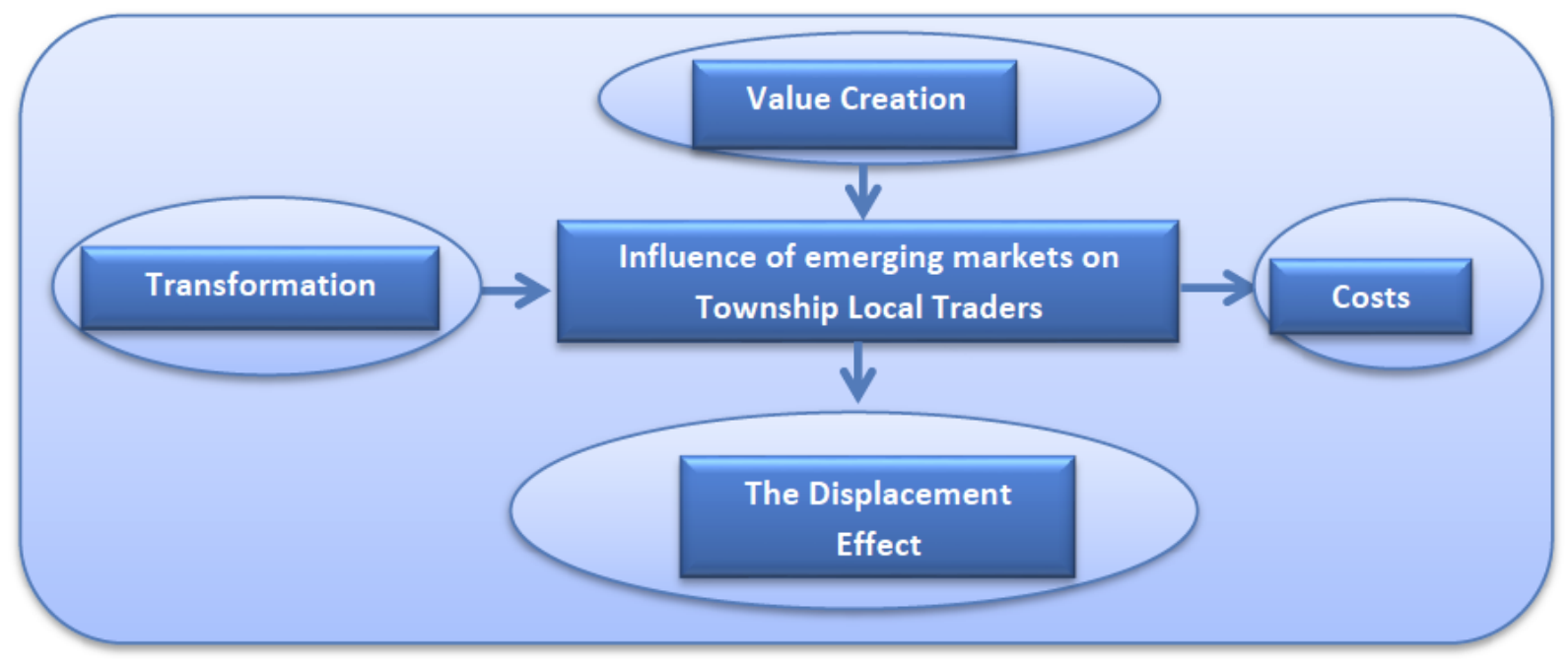

Figure 1: The Conceptual Framework.

Source: Created by researchers from the conceptual framework of this study. 
network can mitigate the magnitude of the displacement of local traders as a result of the entry of both large-scale suppliers and retailers into township markets.

\section{LITERATURE REVIEW}

\subsection{Nature of Scalable Business Sector}

In this study, the scalable business sector subscribes to the business that can sustain and improve capacity and profit margins while the prospects of sales volume are increasing. It means that both small and large scale township businesses have potential and propensity to grow its revenue base rapidly through agile emerging markets than its cost base. The small scale township traders struggle to achieve a multiplication of enterprise value creation in a relatively short time frame. The township traders require the ability to absorb pressure and adapt to emerging markets as a result of township growth and development prospects, while sufficient resources and conducive structure on the markets serve their transformational trajectory. The formal sector generally refers to businesses that are formally registered as tax payers distinguished by influential large chains in the fast moving consumer goods (FMCG) sector are Shoprite/ Checkers, Pick ' $n$ Pay, Woolworths, SPAR, Walmart-Massmart (Makro) and Metro Cash \& Carry (Metcash) (Ligthelm \& Masuku, 2003). These mainstream retailers exert competitive pressure on micro, medium, small scale (SMEs) retailers in townships markets, as some perform both retail and wholesale functions (Radovic, 2013, 17). Cantens $(2012,3)$ elucidates on quantitative perspective associated with small scale: "as the sector reflects limited finances, minimal-volume, low-value trade, limited financial sources and minimal human resources". The author further suggests that the difference between sectoral scale is no longer that clear due to the fact that economic policies tend to push towards formalisation of the township trade zone with a glimpse of imminent success.
However, the small scale sector differs from one economy to the next and can be defined in different terms depending on the particular economy. Callaghan $(2014,333)$ notes that the small scale sector is made up of two different groups. The first is influenced by coping behaviours due to scarce resources or limited earning opportunities in their environment, while the second makes a deliberate, informed decision to become entrepreneurs or desires to move away from structures that are state regulated (Markovic, 2009, 18). The official estimates by the World Bank are that the informal economy in developing countries generates $40 \%$ of Gross Domestic Product (GDP) (Beneke, Curran, Forsyth \& Lamb, 2011, 92). Small local traders are a core source of income and means of survival in developing countries. South Africa is no exception in this regard and township retail activities are common. Woodward, Rolfe, Ligthelm \& Guimaraes $(2011,37)$ observe that multiple methods are used to measure and estimate the extent of the informal sector; these can be divided into direct and indirect approaches.

\subsection{Emerging Markets}

"Emerging markets involve investment by existing retailers or financial institutions using current retail formats and targeting prospective clients" (Tustin \& Strydom, 2006; Hull \& McGroarty, 2014). Growth strategy is largely influenced by saturation in the market and changes in consumer disposable income trends that offer chains stores opportunities to adopt a long-term strategic view that devotes more time and resources to non-traditional township markets. The majority of local townships traders mainly trade in food, clothing and other fast moving consumer goods of minimum to low value ( Strydom \& Klerk, 2006; Qian \& Soopramanien, 2014). These products are similar to those that national retailers and chain stores offer in township malls. The emergence of these national retailers in the township business sphere encourages incremental competition although the biggest challenge

Table 1: Informal Sector Business Models

\begin{tabular}{|c|c|c|c|}
\hline Township General Dealers & Flea Markets & $\begin{array}{c}\text { Local Shebeens and Liquor } \\
\text { Stores }\end{array}$ & Spaza Shops \\
\hline $\begin{array}{l}\text { Stand-alone businesses. Usually } \\
\text { permanent structures built with } \\
\text { bricks in business zoned areas }\end{array}$ & Offer handmade arts and crafts & $\begin{array}{l}\text { Mainly in structures traditionally } \\
\text { used for residential purposes }\end{array}$ & $\begin{array}{l}\text { Small businesses operating in } \\
\text { residential sections }\end{array}$ \\
\hline $\begin{array}{l}\text { Convenient to local residents } \\
\text { offering a wider variety of goods } \\
\text { than a Spaza shop would offer }\end{array}$ & $\begin{array}{l}\text { Operate in high traffic centres } \\
\text { like taxi ranks }\end{array}$ & $\begin{array}{c}\text { Specialize in selling Alcoholic } \\
\text { Beverages }\end{array}$ & $\begin{array}{l}\text { Mainly in structures } \\
\text { traditionally used for } \\
\text { residential purposes }\end{array}$ \\
\hline
\end{tabular}

Source: Ligthem \& Masuku (2003). 
confronting local traders is to compete with established national retailers who exploit economies of scale and assert their dominance in the mainstream sector (Strydom \& de Klerk, 2006, 28). Although the dominance of South African mainstream retail chain stores signifies displacement effects, Ouma, Mwangi, \& Oduk $(2013,33)$ look at "the franchise system that allows for rapid expansion and adds the marketing advantage of local families undertaking the entrepreneurship of expansion".

\subsection{Transformational Emerging Markets}

McGaffin, Napier \& Gavera $(2014,376)$ note that there has been a significant increase in township mall developments in emerging markets in South Africa. In Durban, malls have been developed in Umlazi (Mega City and KwaMnyandu Mall) and the Bridge City Mall in Kwa-Mashu. These shopping malls have changed the face of retail trading for township consumers and local retailers who for many years provided township residents' needs (Beneke et al. $(2011,94)$. The malls widen the range of goods and services to local consumers at competitive prices, and reduce travel costs as well as substantially decrease the total cost of ownership of goods (Klemz, Boshoff \& Mazibuko, 2006, 593). Indeed, the development of township malls has the positive transformation of economic activities in township areas. Logically, an increase in the average size of a retail centre is an indication of increased demand among local consumers in terms of wide variety of products and shift in preferences coupled by an increase in purchasing power (McGaffin \& Gavera, 2011, 15). Kenny $(2011,43)$ and McGaffin \& Gavera $(2011,16)$ point out that each retail centre has an anchor business with such centrality and dominant-led network including Spar Supermarkets, Shoprite Checkers, Pep Stores, Jet, all big four retail banks (ABSA Bank, Nedbank, Standard Bank, First National Bank) including Capitec, and Ithala Banks, and Pick ' $n$ Pay stores. Local businesses also grew as shown by the fact that the local taxi association formally request the extension of the taxi rank (Kenny, 2011, 54), whereby Cambridge Supermarkets seize an opportunity to locate in every major township taxi ranks. In penetrating emerging markets where much remains to be done, developers could look at other options in order to create sustainable economic growth that can yield positive returns for the majority of stakeholders in township mall development (Khanna \& Palepu, 2013; Jürgens \& Donaldson, 2012). In cogitating on different ways of creating value in such communities, (Hills, Russell, Borgonovi, Doty \& Iyer,
2012, 9) suggested that, (1) Improved access to products and services that largely cater for pressing social needs; multinationals would create new markets and new selling opportunities, (2) Enhancing productivity within the value chain and upgrading company operations to drive continuous improvement in quality; improve efficiency while addressing social imbalances and (3) establishing business clusters and a framework guided by conditions that aim to improve the targeted markets, promote business and alleviate social problems (Thompson \& MacMillan, 2010). The authors further illuminated shared value creation as multinationals investing heavily in the communities to suggest establishment of incentive schemes for local businesses and investing heavily in training and developing local business superseding the training and professional competence (Hills, Russell, Borgonovi, Doty \& lyer, 2012, 6).

\subsection{The Displacement Effect}

Strydom (2006, 48) observes that "African consumers are upgraded into the middle-income group, and left township life for urban residential areas". These changes in economic power/emancipation benefited mainstream trade spectrum. However, the paradigm shift in retail markets resulted in mainstream retailers expanding into new economies. Mokgabudi $(2011,2)$ observes that "many members of the previously disadvantaged middle class still reside in townships", representing untapped markets as the large retail chains recognising the potential to broaden their operations to emerging markets (Donaldson \& Du Plessis, 2013, 27). Verick $(2004,2)$ argues that "the informal sector eventually loses due to the expansion of new economies". 'Large scale retail chains are in a strong position to adopt an aggressive pricing strategy, which could prove to be too much of a challenge for the small local retailer who may be eventually be priced out of the market' (Donaldson \& Du Plessis, 2013, 23). Small scale businesses may need to diversify their portfolio, consider new products and/or invest in consumer engagement rather than trying to compete by reducing their prices which may not necessarily make commercial sense for the retailer in the short to medium term. Ligthelm $(2014,2)$ highlighted that "the survivors were businesses that had existed long before the mall was developed and were established due to entrepreneurial reasons other than unemployment issues. These businesses were still managed by their owners that were fully involved in all business operations on a permanent basis". Harrison \& Todes $(2010,26)$ argue that a number of factors other than 
the development of a new mall determine business success or failure. "These factors include economic conditions and business skills as the key factors which may lead to a business being successful or not and only small businesses within a $5 \mathrm{~km}$ radius from the township mall can be considered" (Harrison \& Todes, 2010, 26).

\section{RESEARCH METHODOLOGY}

\subsection{Research Design}

The research design is a strategic framework for action that serves as a link between the research questions and the execution of the research (Patton, $2005,6)$. Wooldridge $(2012,17)$ defines a crosssectional time horizon as 'data sets involving a time dimension such as time series and panel data which requires special treatment because of the correlation across time'. There are three broad research approaches, namely, quantitative, qualitative and mixed method (Venkatesh, Brown \& Bala, 2013, 21). Patton $(2005,2)$ notes that quantitative research provides numerical analysis, percentages and trends (Denzin \& Lincoln, 2011, 1). This paper employed quantitative research methods (frequency and distribution statistics, cross-tabulation and chi-square) to achieve its objectives through the completion of questionnaires. The quantitative approach was appropriate due to "its rigorous approach to understanding, describing and producing detailed explanations of a phenomenon" (Creswell, 2013, 155; Hesse-Biber, 2010, 3) of emerging markets on local traders and the displacement effects. A selfadministered questionnaire was distributed to township retailers in both Umlazi and Kwa-Mashu who voluntarily completed the questionnaire, based on their knowledge, experience and perceptions with the guidance of the researchers. Although quantitative approach is projectable to the population and can be used to test a hypothesis due to the ability to measure data using statistics (Maxwell, 2012, 29), the disadvantages of quantitative research are that "it does not study things in a natural setting, it ignores the context of the study completely and it also involves studying a large population sample" in order to produce reliable results (Bernard and Bernard, 2012; Creswell, 2013). The statistical software Statistical Package for the Social Sciences (SPSS) was used to explore the relationships among variables. The study site was the Durban region with a focus on Umlazi Township and Kwa-Mashu Township which are part of the greater Durban and eThekwini Metropolitan Municipality. As the two biggest townships in the region, Kwa-Mashu is home to 175663 people spread over $21.47 \mathrm{~km}^{2}$ while Umlazi has a population of 404811 spread over 47.46 $\mathrm{km}^{2}$ (Frith, 2014, 12).

\subsection{Target Population \& Sampling Size}

Charmaz $(2011,372)$ defines the target population as "the total population of respondents in a survey". The target population should be defined along "geographical and time lines" (Sekaran \& Bougie, 2010, 267). The target population for this paper was the local traders as respondents impacted by emerging markets in Umlazi and Kwa-Mashu Townships. A study conducted by the eThekwini Economic Development and Investment Promotion Unit has found that there were 750 local traders in Umlazi Township and 420 in Kwa-Mashu Township. Sampling is a process that involves selecting a small portion of the population to represent the entire target population, whereas the sample size is the total number of units or people selected to participate in the study. Adopting Sekeran \& Bougie's $(2010,276)$ sampling method, the researchers looked at a population of 1170 (750 Umlazi plus 420 KwaMashu equals 1170 population augmented to 1400) multiple outlet owners in Umlazi and Kwa-Mashu Townships and the estimated population between the two townships was augmented to 1400 by year 2016 to account for rapid economic development activities and opening of new ventures. The paper drew a sample group of 302 informal township outlets owners (Sekaran \& Bougie, 2010) to whom questionnaires were distributed and 301 were returned. Sekaran \& Bougie $(2010,276)$ describe convenience sampling as the collection of data from "members of the population who are conveniently available to provide responses", when the members of the population are easily available (Charmaz (2011, $375)$. Sekaran \& Bougie $(2010,276)$ note that, in purposive sampling, "information is obtained from specific target groups on nonprobability sampling who can provide the required information, or conform to parameters set by the researcher". It is important that the sample is representative of the population (Levy \& Lemeshow, 2013, 43). The limitation of this paper was that it was conducted in one region, the Durban region. However, the researchers addressed this limitation by targeting high activity business locations, which were the two main townships in this region, Umlazi and KwaMashu townships.

\subsection{Data Collection Instruments}

Data is information collected during the course of the research paper using tools while data collection 
instruments refer to the actual devices used to collect data (Rubin \& Chisnell, 2008, 43). The researchers used questionnaires to collect quantitative data. Qualitative data is described by Sekaran \& Bougie $(2010,444)$ as "data that are not immediately quantifiable, unless they are categorised in some way, whereas quantitative data is generally gathered through structured questions" (Levy \& Lemeshow, $2013,108)$. The instrument was designed to address the quantitative aspects of the research on township traders' perceptions of the effects of value-creation in emerging markets. Perceptions influence whether people reap benefits from the emergence of township malls or are discouraged from trading. The questionnaire is structured in terms of different dimensions; biographical data and organizational profile to profile respondents; dichotomous questions "yes" or "no"; and a five-point Likert scale that ranged from 1 to 5 with 1 being strongly disagree and 5 being strongly agree. The self-administered questionnaire was distributed to township local traders in both Umlazi and Kwa-Mashu who voluntarily completed the questionnaire, based on their knowledge, experience and perceptions with the guidance of the researchers.

\subsection{Data Analysis}

The data was analysed using the SPSS where the responses were converted from categorical data to nominal data in order to enable the data to be partitioned into mutually exclusive and collectively exhaustive categories.

\section{Frequency Distribution on Nature of Business}

Binomial test shows that seventy eight per cent of the respondents used their own transport to fetch goods for resale. A significantly larger proportion of the sample $(73 \%)$ agreed that the cost of obtaining goods had decreased since the malls opened. Similarly, a significantly larger proportion of the respondents $(74 \%)$ stated that they received goods for resale from supplier representatives. Sixty per cent of the respondents said

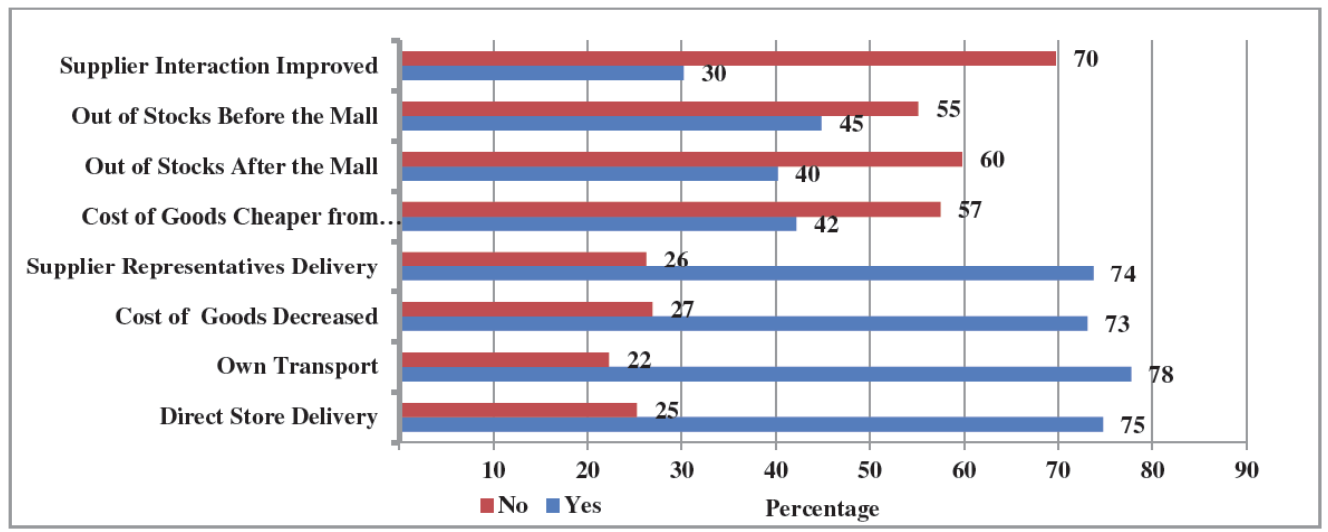

Figure 2: Value Creating Supply Chain Distribution Systems.

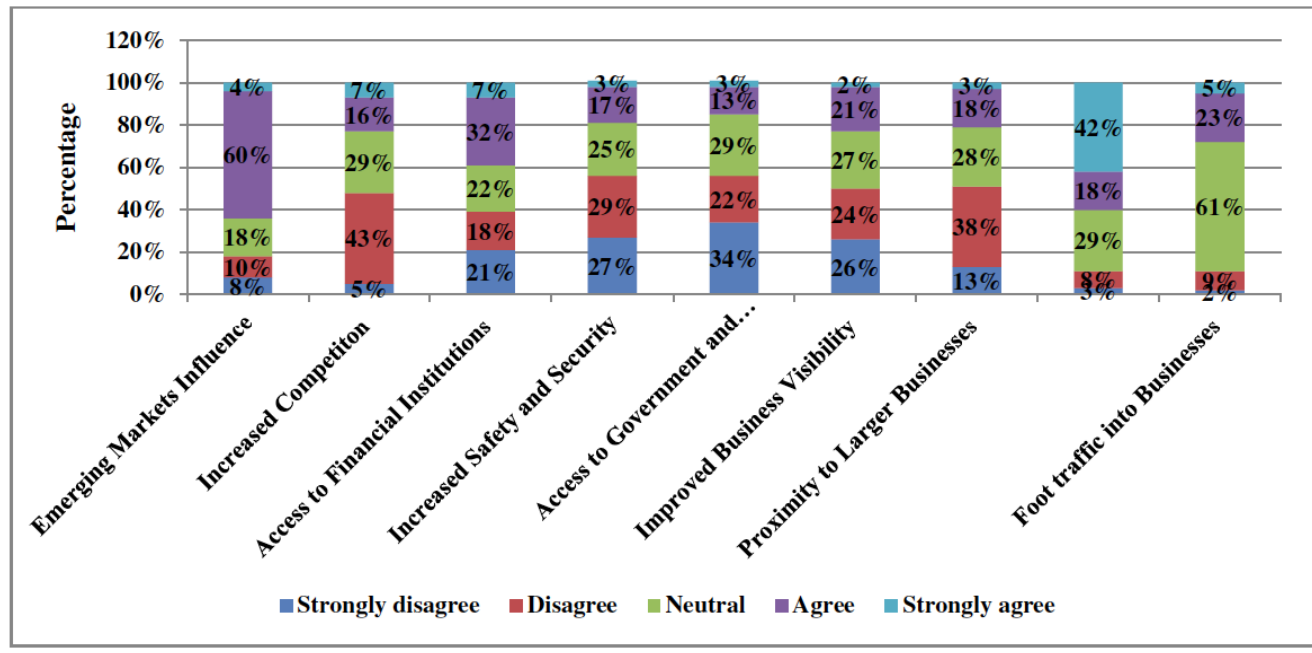

Figure 3: Value Creation and Local Development on the magnitude of Agree or Disagree. 
that they did not run out of stock even after the mall opened, while $40 \%$ did run out of stock even after the mall opened. In contrast, $55 \%$ of the respondents did not run out of stock prior to the mall opening while $45 \%$ did experience stock out prior to the mall opening. Finally, $70 \%$ of the respondents felt that supplier interaction did not improve after the mall opened with $30 \%$ experiencing improvement in supplier interaction after the opening of the shopping malls.

Figure 3 indicates combined agreement of $60 \%$, while a very small percentage $(11 \%)$ disagreed that proximity to public facilities and transport hubs has improved since the malls opened in these townships as the local informal traders are influenced by emerging markets. A large percentage of the respondents (43\%) disagreed that the emergence of township malls brought about increased competition, with $29 \%$ remaining neutral. A combined $39 \%$ of the respondents agreed that access to financial institutions improved with the construction of township malls while a combined $39 \%$ also disagreed with this statement and $22 \%$ were neutral. A combined $56 \%$ of respondents disagreed that safety and security increased after the malls opened. According to $56 \%$ of the respondents, there was no improved access to government and business institutions. There was combined disagreement of $50 \%$ that there was improved visibility of traders' businesses due to the emergence of township malls and only $23 \%$ of the respondents felt that their businesses became more visible due to the emergence of malls. A combined $51 \%$ of the respondents disagreed that that mall development resulted in proximity to larger businesses while $28 \%$ remained neutral and only $21 \%$ agreed with this statement. Finally, a large proportion $(61 \%)$ of the respondents remained neutral on the question of whether mall development had led to an increase in foot traffic into their individual businesses while $11 \%$ disagreed and $28 \%$ agreed.

Table 2 shows that proximity to public facilities and transportation hubs has improved with the opening of the malls (Mean $=3.86$, Std Deviation=1.148). Figure 3 illustrates that there was significant agreement of $60 \%$ that local traders are influenced by emerging markets in townships (Mean $=3.4$, Std Deviation $=1.010$ ). The table further reveals strong neutral feedback from respondents, (61\% in Figure 3 ) in response to the question of whether or not foot traffic into retail businesses has increased since the emergence of malls (Mean $=3.20$, Std Deviation $=0.754$ ). Twenty three per cent of the respondents agreed with the statement that foot traffic increased due to the emergence of malls while only $9 \%$ disagreed and $5 \%$ strongly agreed (Mean $=2.86$, Std Deviation $=1.262$ ) . However, since the mean average responses result is $<3$, it can be tentatively inferred that there is significant disagreement that access to banking and financial institutions has improved. There is significant disagreement that competition has increased since the mall opened $($ Mean $=2.75$, Std Deviation $=1.004$ ) There was also significant disagreement that proximity to larger businesses has improved due to the emergence of township malls (Mean $=2.61$, Std Deviation $=1.036)$. There is a significant disagreement among the respondents (Mean $=2.48$, Std Deviation $=$ 1.139) that visibility of retail business improved due to the emergence of township malls.

$\mathrm{H}_{10}$ : There is a relationship between the performance of traders' businesses and the existence of the mall.

$\mathrm{H}_{1 \mathrm{~A}}$ : There is no relationship between the performance of traders' businesses and the existence of the mall.

Table 2: Descriptive Statistics on Value Creation and Development

\begin{tabular}{|c|c|c|c|c|}
\hline Variables & $\mathbf{N}$ & Mean & Std Deviation & Std Error Mean \\
\hline Proximity to larger Businesses & 301 & 3.86 & 1.148 & 0.066 \\
\hline Local Informal Traders Influenced & 301 & 3.40 & 1.010 & 0.058 \\
\hline Levels of Foot Traffic Increased & 301 & 3.20 & 0.754 & 0.043 \\
\hline Access to Banking and Financial Institutions Improved & 301 & 2.86 & 1.262 & 0.073 \\
\hline Competition Increased & 301 & 2.75 & 1.004 & 0.058 \\
\hline Proximity to Larger Businesses Improved & 301 & 2.61 & 1.036 & 0.060 \\
\hline Visibility of My Business Improved & 301 & 2.48 & 1.139 & 0.066 \\
\hline Safety and Security Increased & 301 & 2.41 & 1.135 & 0.065 \\
\hline Improved Access to Government and Business Institutions & 301 & 2.31 & 1.161 & 0.067 \\
\hline
\end{tabular}


Table 3: Cross-Tabulation - Effect of Malls on Local Trader Businesses

\begin{tabular}{|c|c|c|c|c|c|}
\hline \multicolumn{3}{|c|}{ Cross tabulation: Local trader business and effect of mall } & \multicolumn{2}{|c|}{ Effect of mall } & \multirow[t]{2}{*}{ Total } \\
\hline & & & Positive & Negative & \\
\hline \multirow[t]{5}{*}{$\begin{array}{l}5 \text { Types of } \\
\text { businesses }\end{array}$} & Liquor outlet & Count $\%$ within types of businesses & $\begin{array}{c}20 \\
48.80 \%\end{array}$ & $\begin{array}{c}21 \\
51.20 \%\end{array}$ & $\begin{array}{c}41 \\
100 \%\end{array}$ \\
\hline & Grocery shop & Count $\%$ within types of businesses & $\begin{array}{c}56 \\
47.90 \%\end{array}$ & $\begin{array}{c}61 \\
52.10 \%\end{array}$ & $\begin{array}{c}117 \\
100 \%\end{array}$ \\
\hline & Hawker & Count $\%$ within types of businesses & $\begin{array}{c}22 \\
52.40 \%\end{array}$ & $\begin{array}{c}20 \\
47.60 \%\end{array}$ & $\begin{array}{c}42 \\
100 \%\end{array}$ \\
\hline & Cash \& carry & Count $\%$ within types of businesses & $\begin{array}{c}1 \\
25.00 \%\end{array}$ & $\begin{array}{c}3 \\
75.00 \%\end{array}$ & $\begin{array}{c}4 \\
100 \%\end{array}$ \\
\hline & Tuck-shop & Count $\%$ within types of businesses & $\begin{array}{c}2 \\
2.10 \%\end{array}$ & $\begin{array}{c}95 \\
97.90 \%\end{array}$ & $\begin{array}{c}97 \\
100 \%\end{array}$ \\
\hline \multicolumn{2}{|c|}{ Total } & Count $\%$ within types of businesses & $\begin{array}{c}101 \\
33.60 \%\end{array}$ & $\begin{array}{c}200 \\
66.40 \%\end{array}$ & $\begin{array}{c}301 \\
100.00 \%\end{array}$ \\
\hline \multicolumn{6}{|c|}{ Chi-Square Tests } \\
\hline & & Value & $\begin{array}{l}\text { Degree of } \\
\text { Freedom }\end{array}$ & \multicolumn{2}{|c|}{ Asymp. Significance (2 - sided) } \\
\hline \multicolumn{2}{|c|}{ Pearson Chi-square $\left(x^{2}\right)$} & 64.964 & 4 & \multicolumn{2}{|c|}{.000} \\
\hline \multicolumn{2}{|c|}{ Likelihood Ratio } & 83.19 & 4 & \multicolumn{2}{|c|}{.000} \\
\hline \multicolumn{2}{|c|}{ Linea-by-Linear Association } & 54.601 & 1 & \multicolumn{2}{|c|}{.000} \\
\hline \multicolumn{2}{|c|}{$\mathrm{N}$ of Valid Cases } & 301 & & & \\
\hline
\end{tabular}

a. 2 cells $(20.00 \%)$ have expected count less than 5 . The minimum expected count is 1.34 .

Table 3 above shows that there is a significant relationship between the performance of local township businesses and the existence of the shopping malls $(x 2$ $(8, \mathrm{~N}=301)=120.499, \mathrm{p}<.0005)$. More than the expected number of local township traders' businesses suffered negative effects due to the existence of the malls. Tuck-shop traders showed a higher propensity of a negative effect.

$\mathrm{H}_{20}$ : There is a relationship between the type of business and income generated before the mall opened

$\mathrm{H}_{2 \mathrm{~A}}$ : There is no relationship between the type of business and income generated before the mall opened

$\mathrm{H}_{30}$ : There is a relationship between informal trader businesses and income generated after the mall opened

$\mathrm{H}_{3 \mathrm{~A}}$ : There is no relationship between informal trader businesses and income generated after the mall opened

Tables $\mathbf{4}$ and $\mathbf{5}$ examine the potential relationship between income generated by business types before and after the malls opened. The results show that there is a significant relationship between the Rand value income generated by local traders before the existence of the mall ( $x 2=233.070, p<0.000, D f=12)$ and the Rand value income generated after the malls opened $(\mathrm{X} 2=141.088, p<0.000, \mathrm{Df}=12, \mathrm{~N}=301)$. The majority of local business traders suffered a decrease in monthly income after the malls opened. The total effect is that the income of outlets that made on average less than R5 000 a month before the malls started operating decreased from $35 \%$ to $27 \%$ after the mall started operating, while those that made on average between R5 000 and R10 000 before the mall opened increased their income from $24 \%$ to $61 \%$ after it opened. Furthermore, the income of owners who made on average between R10 000 and R20 000 per month decreased from $38 \%$ to $12 \%$ after the malls started operating. Finally, the income of business owners who made on average more than R20 000 a month before the mall started operating decreased from $3 \%$ to $1 \%$. Therefore, the paper can tentatively accept that there is a strong relationship between the income generated by local business traders before and/or after the township malls were developed with a significance value of $95 \%$. 
Table 4: Income before Mall

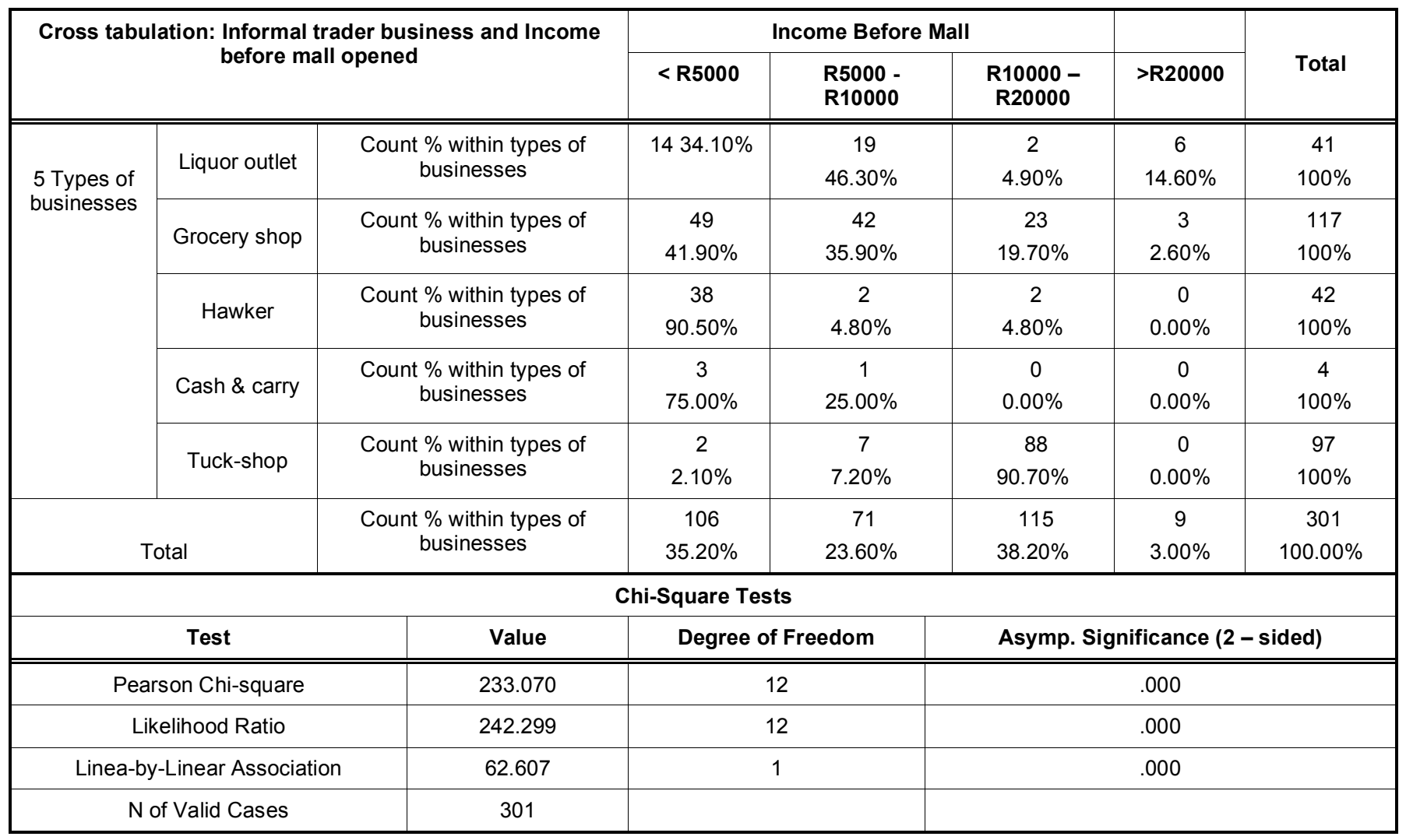

a. 10 cells $(50.00 \%)$ have expected count less than 5 . The minimum expected count is .04 .

Table 5: Income after Mall

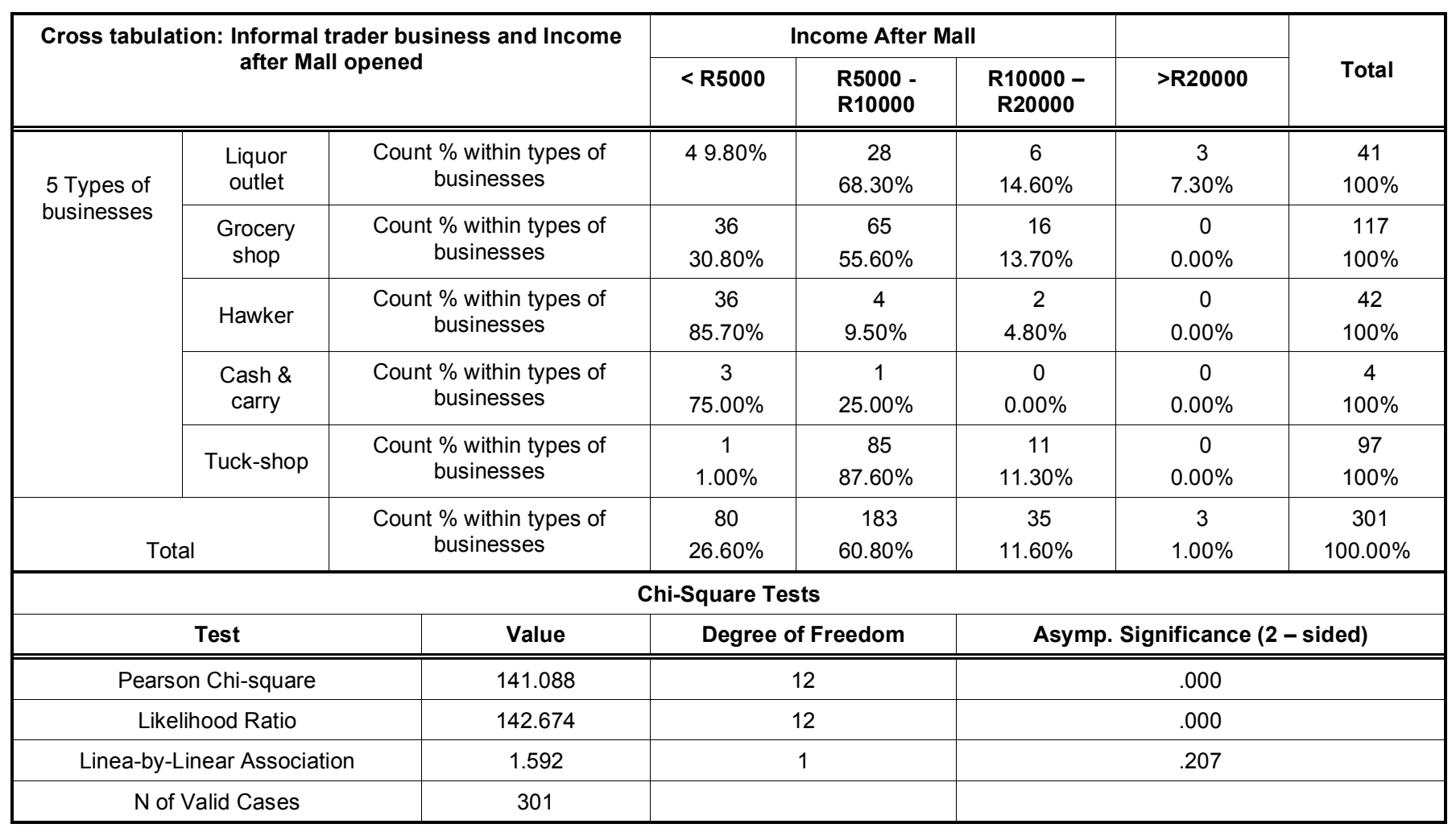

a. 10 cells $(50.00 \%)$ have expected count less than 5 . The minimum expected count is .04 . 


\section{DISCUSSION}

According to Leth \& Hems $(2013,26)$, value creation occurs when large chains invest in underserviced communities which may result in both direct and indirect impacts. Positive impacts could include job creation, improved delivery of goods and services, local development and business enterprise development. On the other hand, negative impacts could occur when improved supply chain distribution systems are implemented. The effects could include, among other things, a loss or decline in return on sales, increased competition and/or being displaced. Township development and improved infrastructure such as roads and water supply could also result, as well as improved safety and security and closer proximity to public facilities. The above analysis is largely based on business owners' perceptions and experiences of how the emerging markets have affected local businesses. Sixty five per cent of the respondents stated that their monthly income did not increase after the malls opened, suggesting that their income decreased, while $35 \%$ indicated that their monthly income increased. Local traders largely trade in breaking bulk, keeping stock which enable consumers to purchase as and when they require goods. They offer an assortment of products based on local demand using pull system and largely informed by convenience for the local township consumer. In managing the flow of products between production and consumption along the supply chain networks, firms in emerging markets utilise innovative and unconventional distribution approaches that are sufficiently flexible to achieve success (Ancarani, Frels, Miller, Saibene \& Barverio, 2014, 32).

Therefore, local traders' overall perception of the emergence of township malls is a negative one. Sixty six per cent of the respondents noted that some local traders had to close their doors/stop trading after the malls opened as they could not survive the competition and those that survived had to change their business model $(64 \%)$. While it could be assumed that mall development would deliver improved road infrastructure, water supply and a better transportation system, $70 \%$ of the respondents stated that their businesses did not benefit from the development of the malls, and only $30 \%$ felt that there were some benefits. The reason could be a decrease in monthly revenue/income, increased competition, a decrease in the number of local traders in and around the malls, changes in product range and an overall decrease in demand. The emergence of township malls could be expected to reduce the cost of goods and services, minimise or eradicate out of stocks at retail level, improve supplier interactions in the form of supplier representatives being more accessible and improve direct store delivery from suppliers. The main purpose of distribution centre ownership is to achieve economies of scale through quantity purchasing discounts (Leenders, Johnson, Flynn \& Fearon, 2008) and forward buys from suppliers wherein, the selling prices to the end-consumer are reduced (Hugo, Badenhorst-Weiss \& Van Biljon, 2008). A large proportion of the respondents $(75 \%)$ agreed that local retailers' goods were delivered directly by suppliers. Direct store delivery implies that improved supply chain distribution systems are in place, enhancing convenience and reducing prices and order lead times for local retailers.

Improved supply chain distribution systems create value for local retailers. Reduced costs could be achieved due to the fact that some suppliers could set up camp within the township malls, thus reducing travelling time and delivery costs. If local retailers are able to purchase goods and services at cheaper rates, they are better able to compete with large chain stores. Effective supply chain distribution systems enable retailers to purchase once in a cycle and reduce the number of delivery trips without running out of stock. The greater significance and the highest means that are above the neutral score for proximity to public facilities such as taxi ranks and financial institutions, increased safety and security and improved access to government and business institutions since the malls opened. These findings suggest that the emergence of township malls has improved the economy at township level. The influence of emerging markets on the costs of distribution systems and the propensity improves product availability, as well as to examine the transformation and development of townships and the effects on local traders. The emerging markets offer an opportunity for investors to improve infrastructure and create job opportunities in communities largely dominated by populations in the lower segment of the income pyramid. However, the cross-tabulation test conducted to measure the performance of local traders after the mall opened revealed a significant relationship between the performance of local businesses and the existence of the mall. The majority of the respondents' businesses suffered due to the construction of township malls. The final objective was to assess the effects of the displacement of local traders as the emerging township economy creates entry for both large scale suppliers and retailers into township 


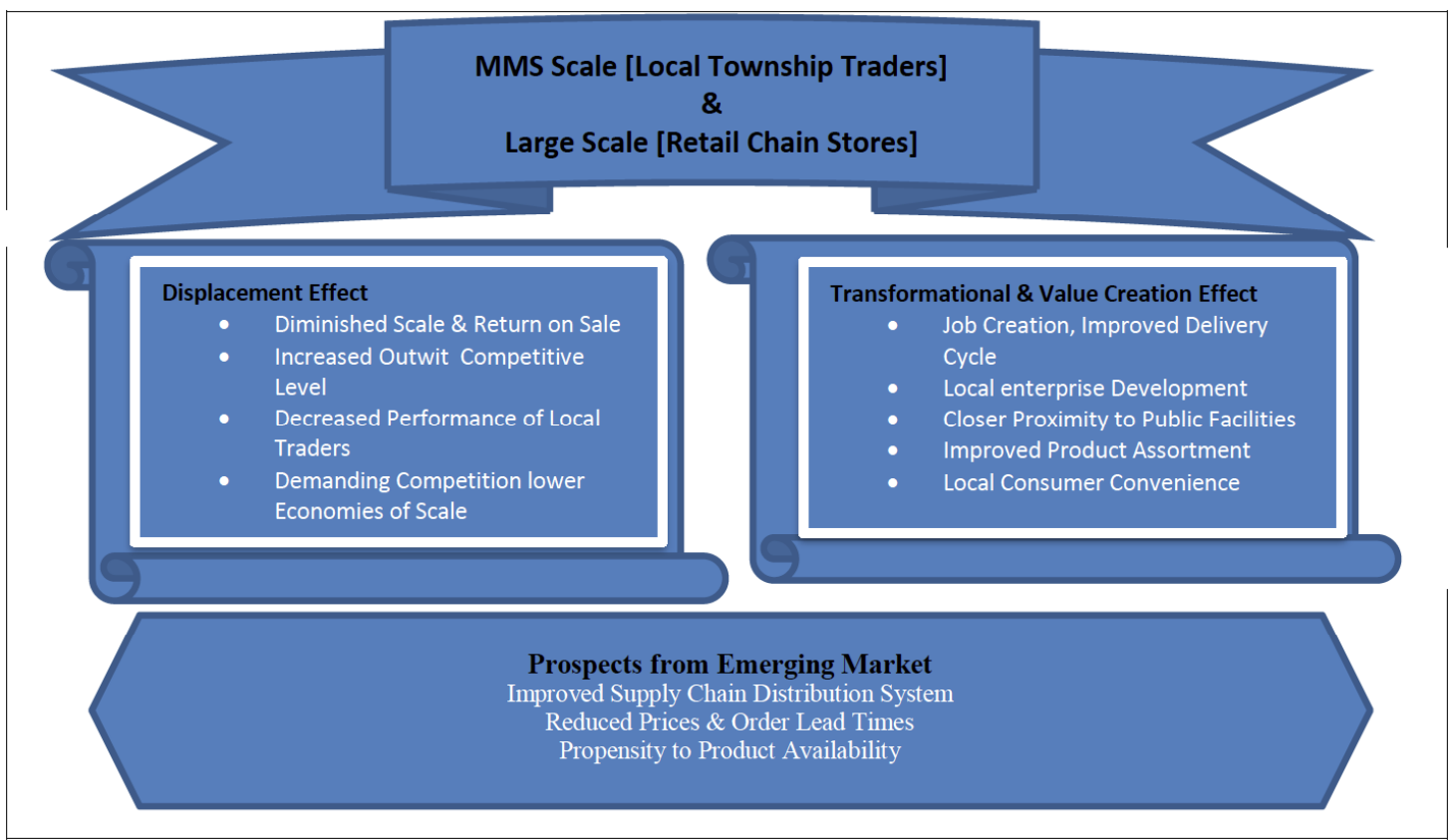

Figure 4: Shared Value Creation for Scale Sectors.

Source: Developed by the researchers.

markets. It was expected that township malls would provide stiff competition for local traders as large chains can source goods and services at lower cost than these traders. According to Coyle, Langley Jr, Novack and Gibson (2013) the system enhances customer service and, contingency protection (against delays and vendor stockouts) allows for a smooth manufacturing process and the integrated service allows for a consolidation of products for delivery and expedites premium transport services combined with supply chain information technology. Tuck-shops, grocery shops and hawkers showed a similar trend with cash \& carries retaining the same level of income. This suggests that some local traders were displaced completely due to the loss of income caused by the emergence of township malls.

The paper tentatively depicted that the displacement of small scale businesses due to lower return on sale, intensified competition by large scale suppliers and retailers and poor economies of scale has the effect on performance for local traders. The shared value creates more positive effects for improved deliver cycle, propensity to job creation, local enterprise development within close proximity and improved product assortment and consumer convenience. The prospects of emerging markets have amenities reflecting improved supply chain distribution system, reduced prices and order lead times, and propensity to product availability. The mixed positive and negative effects on local retailers imply that township mall development can have a relatively positive impact on local trader businesses based on the data collected. Moreover, there was no significant evidence that more businesses or outlets started trading after the malls opened.

\section{DATA ASSESSMENT}

Reliability can be defined as "consistency and the ability to replicate an earlier study design and achieve the same findings, proving the validity of the research" (Mohajan, 2017, 10; Taherdoost, 2016:28 and Heale and Twycross, 2015, 66-67). This paper uses internal consistency to measure the reliability of the selfadministered questionnaire using Cronbach's alpha coefficient. Homogeneity (also referred to as internal consistency), stability and equivalence are three attributes of reliability. "Firstly, homogeneity refers to the ability for items present on a scale can measure one construct; secondly, stability is about repeatedly testing instruments and achieving consistent results; and lastly, equivalence connotes the consistency derived from responses from various users of a specific instrument" (Heale and Twycross, 2015, 67). Researchers utilised the Cronbrach alpha coefficient to "measure the consistency of the items, also known as the scale reliability, which interprets how closely, related a set of items are in a group" (Fritsch, 2016, 12). The Cronbach's Alpha value in this paper is 
0.801 as the scale considered reliable with the sample through assessing nine (9) variables on the five point Likert scale. The paper utilised the Cronbach alpha coefficient to conclude on the reliability and consistency of the data in the questionnaire. Validity is "the degree to which evidence and theory support the interpretations of test scores entailed by the proposed uses" (Fritsch, 2016, 14). Construct validity tested a scale "in terms of the theoretically derived hypotheses concerning the nature of the underlying variable" (Pallant, 2010, 7). Construct validity considers the degree a research tool is able to measure the construct as it intended to measure, furthermore, homogeneity, convergence and theory evidence are used to demonstrate construct validity (Taherdoost, 2016, 28). Content validity is defined as the adequacy with which a measure or scale has sampled from the intended domain of content provided in this paper (Pallant, 2010, 6; Heale and Twycross, 2015, 66).

\section{CONCLUSION}

It could be assumed that due to township malls development, entrepreneurs would seize the opportunity to open new stores in order to cater for the influx of consumers visiting the mall. In contrast, this paper found that some owners closed up shop (displacement effect) as they could not survive the increased competition. The market is based on the survival of the fittest and local traders would likely find it costly and demanding to compete with large scale businesses that exploit economies of scale and are supported by a highly qualified management team. Hypothetically, it has been discovered in this paper that there is a significant relationship between the performance of local traders' businesses and the existence of the malls on both townships. Therefore, the same economic policies that seek to grow small scale economies affect the growth and existence of the developing market. Only two major townships indicate the shortcoming of the paper although the biggest including the second biggest in South Africa delimited the effect of site. This study has to assist in instituting the reforms regarding the initial strategy for township development. The future paper should focus on financial performance and the government interventions from the policy of radical and inclusive economic transformation. It is crucial to look at how the large scale retailers create congruency and collaborative operational approach to township economy.

\section{REFERENCES}

Ancarani, F., Frels, J., Miller, J., Saibene. C. \& Barberio, M. (2014). Winning in Rural Emerging Markets. California Management Review 56, 31-52.

https://doi.org/10.1525/cmr.2014.56.4.31

Beneke, J., Curran, M., Forsyth, G., \& Lamb, S. (2011). Towards an understanding of retailing practices in the second economy: an exploratory study of Western \& Eastern Cape township retailers in South Africa. African Journal of Business and Economic Research 6, 92-108.

Bernard, HR. \& Bernard, HR. (2012). Social research methods: Qualitative and quantitative approaches: Sage.

Callaghan, CW. (2014). Changes in the structure of earnings of informal street traders. Acta Commercii 14, 13 pages. https://doi.org/10.4102/ac.v14i1.193

Cantens, T. (2012). Informal trade practices. WCO Research Paper Series 22.

Charmaz, K. (2011) Grounded theory methods in social justice research. The Sage handbook of qualitative research 4, 359380 .

Coyle, J.J., Langley Jr, C.J., Novack, R.A. \& Gibson, B.J. (2013). Managing Supply Chain: A logistics Approach. $9^{\text {th }}$ Ed., New York: South-Western, Cengage Learning.

Creswell, JW. (2013). Research design: Qualitative, quantitative, and mixed methods approaches: Sage publications.

Denzin, NK. \& Lincoln, YS. (2011) The SAGE handbook of qualitative research: Sage.

Donaldson, R. and Du Plessis, D. (2013). The urban renewal programme as an area-based approach to renew townships: The experience from Khayelitsha's Central Business District, Cape Town. Habitat International 39, 295-301. https://doi.org/10.1016/j.habitatint.2012.10.012

Fritsch, E. (2016). Applied Research Methods. New York: Content Technology Incl publications.

Frith, A. (2014). Census 2011. URL: http://census2011. adrianfrith. com/place/199018 (visited on 12/12/2012).

Gonzalez, S. \& Waley, P. (2013). Traditional retail markets: The new gentrification frontier? Antipode https://doi.org/10.1111/j.1467-8330.2012.01040.x

Harrison, P. \& Todes, A. (2010). Spatial Considerations in the Development of Urban Policy in South Africa: A Research paper as Input into the repreparation of the integrated Urban Development Framework (IUDF).

Hauke, J. \& Kossowski, T. (2011). Comparison of values of Pearson's and Spearman's correlation coefficients on the same sets of data. Quaestiones Geographicae 30, 87-93. https://doi.org/10.2478/v10117-011-0021-1

Heale, R. \& Twycross, A. (2015). Validity and reliability in quantitative studies. Evidence Based Nursing, 18(3), 66-67. https://doi.org/10.1136/eb-2015-102129

Hesse-Biber, S.N. (2010). Mixed methods research: Merging theory with practice: Guilford Press.

Hills, G., Russell, P., Borgonovi, V., Doty, A. \& Lyer, L. (2012). Shared Value in Emerging Markets. How Multinational Corporations Are Redefining Business Strategies to Reach Poor or Vulnerable Populations. FSG.(Retrieved: http://sharedvalue.org/sites/default/files/resourcefiles/Shared _Value_in_Emerging_Markets. pdf).

Hugo, W.M.J, Badenhorst-Weiss, J.A. \& Van Biljon, E.H.B (2008). Supply chain Management: Logistics in perspective. Pretoria: Van Schaik Publishers.

Hull, M. \& McGroarty, F. (2014). Do emerging markets become more efficient as they develop? Long memory persistence in equity indices. Emerging Markets Review 18, 45-61. https://doi.org/10.1016/j.ememar.2013.11.001 
Jürgens, U. \& Donaldson, R. (2012). A review of literature on transformation processes in South African townships. Urban Forum. Springer, 153-163. https://doi.org/10.1007/s12132-012-9149-x

Kenny, B. (2011). Reconstructing the Political: Mall Committees and South African Precarious Retail Workers. TRAVAIL, capital et société 44.

Khanna, T. \& Palepu, K. (2013). Winning in emerging markets: $A$ road map for strategy and execution: Harvard Business Press.

Klemz, BR., Boshoff, C. \& Mazibuko, N-E. (2006) Emerging markets in black South African townships: Small local independently owned versus large national retailers. European Journal of Marketing 40, 590-610. https://doi.org/10.1108/03090560610657859

Leenders, M.R., Johnson, P.F., Flynn, A.E. \& Fearon, H.E. (2008). Purchasing and Supply management: with 50 supply chain cases. $13^{\text {th }}$ Ed. New York: McGraw-Hill.

Leth, M. \& Hems, L. (2013). The Potential for Creating Shared Value in Australia How Australian companies co-create long-term commercial and social value Draft Insights for a Green Paper. Presented at the Creating Shared Value Forum.

Levy, P.S. \& Lemeshow, S. (2013). Sampling of populations: methods and applications: John Wiley \& Sons.

Ligthelm, A. (2014). Confusion about entrepreneurship? Formal versus informal small businesses. Southern African Business Review 17, 57-75.

Ligthelm, A. \& Masuku, T. (2003) Size, structure and profile of the informal retail sector in South Africa: Bureau of Market Research, University of South Africa.

Markovic, M.R. (2009). Globalization and gender participation in the informal sector in developing and transitional countries. E+M Ekonomie a Management: 17.

Maxwell, JA. (2012) Qualitative research design: An interactive approach: An interactive approach: Sage.

McGaffin, R., Napier, M. \& Gavera, L. (2014). Value Capture in South Africa-Conditions for their Successful Use in the Current Legal Context. Urban Forum. Springer, 375-387. https://doi.org/10.1007/s12132-013-9211-3

Mohajan, H. (2017). Two Criteria for Good Measurements in Research: Validity and Reliability. Annals of Spiru Haret University. Economic Series, 17(4), 59-82. https://doi.org/10.26458/1746

Mokgabudi, L. (2011). The impact of shopping mall developments on consumer behaviour in township areas. Masters Dissertation, Unpublished. Pretoria: University of Pretoria.

Neves, D. \& Du Toit, A. (2012). Money and sociality in South African informal economy, Africa 82(1), 131-149. https://doi.org/10.1017/S0001972011000763

Ouma, D., Mwangi, T. \& Oduk, P.M. (2013). Modeling Agility in Kenyan Supermarkets Chain Expansion. International Journal of Business and Commerce 2, 21-36.

Pallant, J. (2010) Survival manual. New York:.McGraw-Hill Education.

Patton, M.Q. (2005). Qualitative research: Wiley Online Library. https://doi.org/10.1002/0470013192.bsa514
Qian, L. \& Soopramanien, D. (2014). Using diffusion models to forecast market size in emerging markets with applications to the Chinese car market. Journal of Business Research 67, 1226-1232.

https://doi.org/10.1016/j.jbusres.2013.04.008

Radovic, M.M. (2013). An evaluation of sme development in Serbia. Актуальні проблеми економіки: 422-431.

Rubin, J. \& Chisnell, D. (2008). Handbook of usability testing: how to plan, design and conduct effective tests: John Wiley \& Sons.

Sekaran, U. \& Bougie, R. (2010). Research methods for business: A skill building approach. Wiley. London.

Soopramanien, D. \& Qian, L. (2014) Using diffusion models to forecast market size in emerging markets with applications to the Chinese car market. Journal of Business Research 67, 1226-1232.

https://doi.org/10.1016/j.jbusres.2013.04.008

Strydom, J. (2011). Retailing in disadvantaged communities: the outshopping phenomenon revisited. Journal of Contemporary Management 8, 150-172.

Strydom, M. \& de Klerk, H.M. (2006). The South African clothing industry: problems experienced with body measurements. Journal of Family Ecology and Consumer Sciences/Tydskrif vir Gesinsekologie en Verbruikerswetenskappe 34. https://doi.org/10.4314/jfecs.v34i1.52904

Taherdoost, H. (2016). Validity and Reliability of the Research Instrument; How to Test the Validation of a Questionnaire/Survey in a Research. SSRN Electronic Journal, 5(3), 28-36. Available at: https://www.researchgate.net/publication/319998004_Validity _and_Reliability_of_the_Research_Instrument_How_to_Test the_Validation_of_a_QuestionnaireSurvey_in_a_Research. [Accessed 10 August 2018].

Thompson, J.D. \& MacMillan, I.C. (2010). Business models: Creating new markets and societal wealth. Long Range Planning 43, 291-307. https://doi.org/10.1016/j.Irp.2009.11.002

Tustin, D. \& Strydom, J. (2006). The potential impact of formal retail chains' expansion strategies on retail township development in South Africa. Southern African Business Review 10, 4866.

Venkatesh, V., Brown, S.A. \& Bala, H. (2013). Bridging the qualitative-quantitative divide: Guidelines for conducting mixed methods research in information systems. MIS quarterly $37,21-54$. https://doi.org/10.25300/MISQ/2013/37.1.02

Verick, S. (2004). Threshold Effects of Dismissal protection legislation in Germany.

Wedan, Q. (2006) Transforming global logistics for strategic advantage in emerging markets. IBM Global Business Services," Whiten Paper.

Woodward, D., Rolfe, R., Ligthelm, A. \& Guimaraes, P. (2011). The viability of informal microenterprise in South Africa. Journal of Developmental Entrepreneurship 16, 65-86. https://doi.org/10.1142/S1084946711001719

Wooldridge, J. (2012). Introductory econometrics: A modern approach: Cengage Learning.

DOI: https://doi.org/10.6000/1929-7092.2019.08.121

(c) 2019 Dlamini and Mbhele; Licensee Lifescience Global.

This is an open access article licensed under the terms of the Creative Commons Attribution Non-Commercial License (http://creativecommons.org/licenses/by-nc/3.0/) which permits unrestricted, non-commercial use, distribution and reproduction in any medium, provided the work is properly cited. 